\title{
Classification of Various Bottled Mineral Waters Marketed in Djibouti
}

\section{Elmi Idil Mouhoumed ${ }^{*}$, Mohamed Mohamed-awal Abdillahi' ${ }^{1}$, Yacin Mouhoumed Elmi², Choukri Osman Doubad1, Egueh Abdoul-Nasser Dirieh³}

\author{
${ }^{1}$ Faculty of Sciences, University of Djibouti, Djibouti, Republic of Djibouti \\ ${ }^{2}$ European Union Cell, External Financing Department, Djibouti, Republic of Djibouti \\ ${ }^{3}$ Ministry of National Education and Vocational Training, Djibouti, Republic of Djibouti \\ Email: *idil_mouhoumed_elmi@univ.edu.dj
}

How to cite this paper: Mouhoumed, E.I. Abdillahi, M.M., Elmi, Y.M., Doubad, C.O. and Dirieh, E.A.N. (2020) Classification of Various Bottled Mineral Waters Marketed in Djibouti. World Journal of Engineering and Technology, 8, 720-738.

https://doi.org/10.4236/wjet.2020.84052

Received: August 14, 2020

Accepted: November 6, 2020

Published: November 9, 2020

Copyright (C) 2020 by author(s) and Scientific Research Publishing Inc. This work is licensed under the Creative Commons Attribution International License (CC BY 4.0)

http://creativecommons.org/licenses/by/4.0/

\begin{abstract}
In this study, nineteen different brands of bottled mineral waters ( 7 brands local and 12 brands imported) were collected from supermarkets and independent food stores throughout Djibouti. The chemical composition mentioned on the labels of the nineteen bottled mineral waters has made the subject of a first verification by Ionic Balance Error (IBE). It was found out of the nineteen brands selected, 12 brands ( 2 brands local and 10 brands imported) had acceptable charge balance error. Correlation Analysis (CA), Principal Component Analysis (PCA) and Hierarchical Cluster Analysis (HCA) were used to analyze the data collected from the labels of bottled water. The obtained results showed that the 12 brands of studied waters can be grouped in 4 distinct classes with similar chemical characteristics. Two local and one imported brands have the same chemical composition but marketed under different names. It was observed that the chemical content local water brands were within the normal range prescribed by both WHO and USEPA except five imported water brands that have concentration values $\mathrm{Ca}, \mathrm{HCO}_{3}, \mathrm{Mg}$ and $\mathrm{SO}_{4}$ beyond acceptable standards. Total hardness values classified most of the studied brands from moderate to very hard water.
\end{abstract}

\section{Keywords}

Bottled Mineral Water, Chemical Composition, Djibouti, Statistical Analysis

\section{Introduction}

The Republic of Djibouti is located in the northeast of the African continent, between the Aden Gulf and the Red Sea. It has a population of about 950,000 
with an area of $23.200 \mathrm{~km}^{2}$. Djibouti is characterized by the severity of its climatic conditions. The climate is hot and dry. Temperatures are high from $30^{\circ} \mathrm{C}$ to over $45^{\circ} \mathrm{C}$ resulting in a high potential evapotranspiration of more than 2000 $\mathrm{mm}$ on average. Annual rainfall is low (150 $\mathrm{mm} /$ year on average) and irregular. Djibouti has some of the lowest water resources in the world, most of which comes from aquifers. The over-exploitation of aquifers and the high pumping rate contribute to an increase in the salinity and promote the development of brackish water. The salinity of much of this water greatly exceeds the standards of the World Health Organization (WHO) [1]. However, tap water is drinkable, but its quality is not guaranteed (problems of infiltration in the pipes in case of rain, for example) and a rather salty flavor. For this reason, many people prefer to drink bottled mineral water to tap water.

Bottled water represents one of the fastest-growing drinks market in the world and recent projections indicate that it is likely to overtake soft drinks and become the largest beverage category by volume. Although more expensive than tap water, the consumption of bottled water increased considerably in the last decades, even in countries where tap water quality is considered excellent. Using data from an internet survey of Swiss and German respondents $(\mathrm{N}=849)$ on water consumption, results suggest that psychological factors play a role in water consumption choice [2]. On other study, a survey of consumer usually stresses two main factors: dissatisfaction with tap water organoleptics (especially taste) and health/risk concerns. However, many other factors are involved, including demographic variables and the perceived quality of the water source [3].

In 2017, bottled water volume grew to 13.7 billion gallons, a 7 percent increase over the previous year, Beverage Marketing Corporation (BMC) said in statement. Bottled water sales now total $\$ 18.5$ billion, an increase of 8.8 percent. Per capita consumption saw a 6.2 percent increase from last year, exceeding over 42 gallons of bottled water. BMC statistics show this is a result of the average annual intake of carbonated soft drinks (CSDs) falling to 37.5 gallons [4].

Long dominated by imports, the mineral water market gradually developed in Djibouti since 2002, with the emergence of new companies. This development has materialized in the implementation of seven units of exploitation and production throughout the entire national territory. It was also accompanied by an exceptional increase in the consumption whose per capita share has changed remarkably. Many authors have sought to give a definition of "mineral water": some involved temperature (but not all mineral water are hot); others the rate of mineralization (but some of them are not very mineralized); others still the mode of deposit or the origin of the water. It is difficult to find a physico-chemical definition of mineral water that is strictly acceptable the only one currently accepted is an administrative definition [5]. This situation prompted the Government of Djibouti to promulgate a series of regulatory texts [6] aimed at regulating the exploitation, production and marketing of bottled water. Bottled drinking water is used by consumers not only for drinking but also for the preparation of infant formula, for cooking, skin care, cleaning contact lenses and filling humidifiers 
[7]. It is interesting to recall that Decree (No. 2001-0010/PR/ MCIA) regulates packaged water intended for human consumption in the Republic of Djibouti. However, this decree does not set limits for the concentrations of 8 major ions the natural mineral water [8].

Multivariate analyses have been often used for the classification and comparison of different samples of water [9] [10] [11]. Also this technique applied for water quality investigations [12] [13] [14] [15] [16]. The application of multivariate analysis, such as correlation analysis (CA), principal component analyses (PCA), the main advantage of hierarchical cluster analysis (HCA) is that it helps analyzing large and complicated data, which have many variables and experimental units. Many studies have been performed to classify the bottled water according to their element contents using by multivariate statistical analysis. Alhassan H. Ismail et al. were used the Hierarchical cluster analysis (HCA) to classify fifteen bottled waters brands. It grouped the 15 bottled waters brands into five clusters of similar water quality characteristics [17]. H.A. Ghrefat conducted a study on classification of 54 brands bottled drinking waters in Saudi Arabia, using a multivariate methods including correlaction Analysis (CA), Principal Components Analysis (PCA) and Hierachical Cluster Analysis (HCA). The resultats demonstrated that the application of different mutivariate statistical techniques provided information on the composition of water and characterized them according to their sources [18]. Aleksander Astel et al. studied the characterization of forty seven bottled mineral waters marketed in poland using hierachical cluster analysis (HCA). It has been shown in this study that all brands analyzed were divided into four major groups [19]. Jelena D. Cvejanoc and Biljana D. Skrbic studied analysis the contents of major ions -and total dissolved solids (TDS) in 33 bottled waters from the Serbian market by principal component (PCA) and hierarchical cluster (HCA) in order to investigate if these techniques could provide the information necessary for classifications of the water brands marketed in Serbia. Results showed that the waters were separated into three main clusters according to their levels of TDS, $\mathrm{Na}^{+}$and $\mathrm{HCO}_{3}^{-}$; sub-clustering revealed a group of soft waters with the lowest total hardness [20]. T. Sghaier and Ben Abdallah studied the classification of the most used twenty marks of conditioned water in Tunisia according to their content of chemical elements constitutes the main objective of this work. Cluster analysis and principal component analysis were used to analyze the data collected from the labels of bottled water. The obtained results showed that the twenty marks of studied water can be grouped in 10 distinct classes with similar chemical characteristics [21]. Other similar studies have been conducted. Versari et al. characterized bottled mineral waters (132 samples) from 19 districts of Italy by means of the physico-chemical and chemical composition (30 parameters) reported on their label by using statistical analysis. The relationships among 12 selected variables were examined by principal component analysis; then, hierarchical cluster analysis was used to search the "natural" grouping among the mineral waters, and linear discriminant analysis allowed to check the reliability of classification [22]. Cüneyt Güler 
studied the characterization 130 Turkish bottled waters brands by using multivariate pattern recognition methods. The production licenses provided information on up to 34 physico-chemical parameters and were a valuable information source for this study. The relationships among eight selected major ion chemistry variables (calcium, magnesium, sodium, potassium, chloride, sulfate, bicarbonate, and fluoride) were examined by principal components analysis and hierarchical cluster analysis [23]. In this study, K. Yekdeli Kermanshahi et al. investigated the chemical composition of 73 Iranian bottled waters brands by correlation analysis (CA), principal component analysis (PCA) and hierarchical cluster analysis (HCA). It was discovered in this study that only 26 brands had eight important parameters such as calcium, magnesium, potassium, sodium, chloride, sulphate, bicarbonate and fluoride and 20 brands had an acceptable load balance Fault. The results showed that Iranian bottled water can be divided into eleven different types of water were identified in which the most frequently observed types were $\mathrm{Mg}-\mathrm{HCO}_{3}$ [24].

According to the available literature on the subject, the results obtained demonstrated that the use of different multivariate statistical techniques (CA, PCA and HCA) provided information on the chemical composition of water and characterized them according to the nature geochemical of exploitations sources.

The purpose of this study is the classification the bottled water brands drinking in Djibouti by means of multivariate analysis using on chemical composition mentioned on the manufacturer labels. Then we will compare the results obtained with World Health Organization (WHO) and United State Environment Protection Agency (USEPA) standards.

\section{Materials and Methods}

\subsection{Bottled Water Database}

Nineteen brands of bottled mineral waters were used for this study out of which seven are local brands and twelve mineral waters are imported brands. We bought those bottled in local supermarkets and independent food stores throughout Djibouti (Table 1). The water samples were collected between January and March 2019. As indicated on their labels, all the sample bottled were

Table 1. Local and imported bottled water brands from Djibouti market.

\begin{tabular}{ccc}
\hline Local bottled water brands & \multicolumn{2}{c}{ Imported bottled water brands } \\
\hline Bio & Al ain & Hépar \\
Iljano & Bahçepinar & Mont Blanc \\
VItall & Contrex & Thonon \\
Palmaraie & Courmayeur & Volvic \\
Okar & Evian & Super Gulf \\
Tayse-Le & Hayat & \\
Biyo Safi & Hamidiye &
\end{tabular}


validated for one year from the production date as per the Djibouti Ministry of Health certification. All bottled water were in polyethylene terephthalate (PET) containers with plastic screw caps. The capacity of these bottled varies from 0.5 to 2 liters. The data collected on the chemical characteristics of the main brands of water marketed in Djibouti comes directly from the labels glued to the bottled available on the market (eight important parameters appear most often i.e. $\mathrm{Ca}^{2+}$, $\mathrm{Mg}^{2+}, \mathrm{Na}^{+}, \mathrm{K}^{+}, \mathrm{Cl}^{-}, \mathrm{NO}_{3}^{-}, \mathrm{HCO}_{3}^{-}$and $\mathrm{SO}_{4}^{2-}$ ).

\subsection{Multivariate Statistical Analysis}

Mineral water composition was studied by means of correlation analysis (CA), principal component analysis (PCA) and hierarchical cluster analysis (HCA) using Statistical Package for the Social Sciences (SPSS version 20) and SPAD. Application of multivariate analysis to complex data sets has attracted high scientific interest in recent years and they are now used in a wide range of application. Several multivariate statistical based studies have been performed to analyze bottled water utilizing different physico-chemical parameters [9] [15] [16].

\subsection{Correlation Analysis}

Correlation analysis was applied to describe the degree of relation between two water chemistry parameters. Correlation is the ratio of the covariance of two variables to the product of their standard deviations [25]. The resulting correlation coefficient is a unitless number that ranges between -1.0 and +1.0. A value of -1.0 represents a perfect inverse relationship between the two variables, whereas +1.0 occurs when the two variables react in exactly the same way as their values change. A correlation coefficient of zero suggests that the two variables are independent of each other.

\subsection{Principal Component Analysis}

Principal component analysis was used to examine the relationships among the variables. In fact, this method helps to reduce the number of variables in the data matrix, to select the most discriminating parameters and to investigate to the overall variation of data. This method can be performed only if correlation among variables in the data matrix occurs [26]. Rotation of principal components was carried out using the varimax normalized method and only factors with eigenvalues greater than one were taken into consideration [27].

\subsection{Hierarchical Cluster Analysis}

Hierarchical cluster analysis is a combination of techniques to classify large data into clusters on the basis of similarities or dissimilarities. Thus, resulting groups are similar to each other but distinct from other groups. In this study, HCA was used for searching the natural grouping among bottled water from different brands. The bottled water brands were classified according to their major ion composition. The data were standardized and the Euclidean distance was used as 
similarity measurement. The Ward's method was used to obtain hierarchical associations. The result of the HCA is presented as a dendrogram with the numbers of groups selected based on visual examination of the dendrogram.

\section{Results and Discussion}

\subsection{Physicochemical Composition of Bottled Mineral Water}

The chemical composition of nineteen bottled mineral waters marketed in Djibouti is summarized in Table 2. However, it is interesting to control the quality and consistency of the analysis carried out in major ions of bottled water. Calculation of the ionic balance error is essential to be able to present and to interpret the results of analyzes displayed on the labels of these bottled [5].

\subsection{Ionic Balance Error}

Water has a net neutral charge and therefore the positive charge contributed by the cations must equal the negative charge contributed by the anions, Equation (1):

$$
\left(\sum \text { cations }\right)=\left(\sum \text { anions }\right)
$$

Table 2. Chemical composition reported on the label of nineteen bottled waters from the Djibouti market.

\begin{tabular}{|c|c|c|c|c|c|c|c|c|c|c|}
\hline No & Brands names & $\mathrm{pH}$ & $\begin{array}{l}\mathrm{HCO}_{3}^{-} \\
(\mathrm{mg} / \mathrm{l})\end{array}$ & $\begin{array}{c}\mathrm{Cl}^{-} \\
(\mathrm{mg} / \mathrm{l})\end{array}$ & $\begin{array}{l}\mathrm{NO}_{3}^{-} \\
(\mathrm{mg} / \mathrm{l})\end{array}$ & $\begin{array}{c}\mathrm{SO}_{4}^{2-} \\
(\mathrm{mg} / \mathrm{l})\end{array}$ & $\begin{array}{c}\mathrm{Ca}^{2+} \\
(\mathrm{mg} / \mathrm{l})\end{array}$ & $\begin{array}{l}\mathrm{Mg}^{2+} \\
(\mathrm{mg} / \mathrm{l})\end{array}$ & $\begin{array}{c}\mathrm{K}^{+} \\
(\mathrm{mg} / \mathrm{l})\end{array}$ & $\begin{array}{c}\mathrm{Na}^{+} \\
(\mathrm{mg} / \mathrm{l})\end{array}$ \\
\hline 1 & Bio & 7 & 49 & 31 & 2 & 5 & 8 & 6 & 1 & 31 \\
\hline 2 & Tayse-Le & 7.1 & - & 20 & 9 & - & 14 & 12 & 10 & 8 \\
\hline 3 & Vitall & 7 & 34.7 & 30.44 & ${ }^{*}<$ L.D & 25.42 & 36.2 & 9.75 & 10.86 & 22.85 \\
\hline 4 & Biyo Safi & 7 & 30 & - & - & - & 30 & 5 & - & - \\
\hline 5 & Iljano & 7.2 & 30 & 60 & 0 & 20 & 15 & 9 & 0.1 & 11 \\
\hline 6 & Okar & 7.3 & 30 & 40 & $<0.3$ & 5 & 8 & 13 & 2 & 8 \\
\hline 7 & Palmaraie & 7.3 & 30 & 40 & $<0.3$ & 5 & 8 & 13 & 2 & 8 \\
\hline 8 & Evian & 7.2 & 360 & 10 & 3.8 & 14 & 80 & 26 & 1 & 6.5 \\
\hline 9 & Hépar & 7.2 & 383.7 & - & 4.3 & 1530 & 549 & 119 & - & 14.2 \\
\hline 10 & Volvic & 7 & 74 & 15 & 7.3 & 9 & 12 & 8 & 6 & 12 \\
\hline 11 & Hayat & 7.55 & 86.9 & 4.1 & - & 2.74 & 19.37 & 4.02 & $<0.2$ & 2.2 \\
\hline 12 & $\mathrm{Al}$ ain & 7.3 & 30 & 40 & $<0.3$ & 5 & 8 & 13 & 2 & 8 \\
\hline 13 & Super Gulf & 7.2 & 14 & 30 & 0.7 & 44 & 22 & 10 & 1.1 & 2.7 \\
\hline 14 & Courmayeur & 7.7 & 170 & 0.3 & $<2$ & 1412 & 576 & 52 & 1.8 & 0.6 \\
\hline 15 & Mont Blanc & 7.6 & 65 & $<1$ & $<1$ & 32 & 29 & 2.4 & 1.9 & 1.6 \\
\hline 16 & Contrex & 7.4 & 372 & - & - & 1121 & 468 & 74.5 & - & 9.4 \\
\hline 17 & Hamidiye & 6.93 & - & 4,18 & - & - & 0.3 & 0.06 & - & 3.7 \\
\hline 18 & Bahçepinar & 7.75 & - & 6.93 & - & 4.77 & - & - & - & 2.17 \\
\hline 19 & Thonon & 7.4 & 340 & 14 & 8 & 12 & 92 & 16 & $<1$ & 6 \\
\hline
\end{tabular}

${ }^{\star}$ L.D: Limit of Detection. 
Of the 19 physico-chemical variables (consisting of major ions, minor ions, trace elements, and physical parameters) in the compiled database, eight variables $\left(\mathrm{Ca}^{2+}, \mathrm{Mg}^{2+}, \mathrm{Na}^{+}, \mathrm{K}^{+}, \mathrm{Cl}^{-}, \mathrm{NO}_{3}^{-}, \mathrm{HCO}_{3}^{-}\right.$and $\left.\mathrm{SO}_{4}^{2-}\right)$ occur most often and were thus utilized by the multivariate pattern recognition methods. Analysis of chemical and physical properties of these bottled waters was carried out by official laboratories that have been certified by the Djiboutian government and accuracy and precision of the laboratory results were not questioned in this study.

However, the chemical composition of the nineteen bottled mineral waters has made the subject of a first verification by Ionic Balance Error (IBE). According to Freeze and Cherry, the percentage ionic balance error is calculated as Equation (2) [28]:

$$
\operatorname{IBE}(\%)=\left(\left(\sum \text { cations }-\sum \text { anions }\right) /\left(\sum \text { cations }+\sum \text { anions }\right)\right) \times 100
$$

The ionic balance method allows to control the quality of the analysis carried out on the major elements. This validation process is a prerequisite for a reliable presentation of the results of analysis and their interpretation. The IBE can be positive or negative. A positive IBE indicates that the water sample has a higher concentration of cations than anions. Conversely, a negative IBE indicates that anions are more abundant.

Table 3 represents the IBE calculated on each of the mineral water samples.

Table 3. Ionic Balance Error (IBE) for mineral waters.

\begin{tabular}{|c|c|c|c|c|c|}
\hline No & Brands names & $\sum$ cations $(\mathrm{meq} / \mathrm{L})$ & Eanions (meq/L) & IBE (\%) & \\
\hline 1 & Bio & 2.27 & 1.79 & 11.83 & \\
\hline 2 & Tayse-Le & 1.63 & 0.863 & 30.8 & - \\
\hline 3 & Vitall & 3.88 & 1.94 & 33.4 & \\
\hline 4 & Biyo Safi & 1.91 & 0.476 & 60.1 & - \\
\hline 5 & Iljano & 1.97 & 2.58 & -13.4 & \\
\hline 6 & Okar & 1.87 & 1.71 & 4.45 & \\
\hline 7 & Palmaraie & 1.87 & 1.71 & 4.45 & \\
\hline 8 & Evian & 6.45 & 6.35 & 0.77 & \\
\hline 9 & Hépar & 37.9 & 38.0 & -0.22 & \\
\hline 10 & Volvic & 1.93 & 1.90 & 0.81 & \\
\hline 11 & Hayat & 1.40 & 1.55 & -5.14 & \\
\hline 12 & $\mathrm{Al}$ ain & 1.87 & 1.71 & 4.45 & \\
\hline 13 & Super Gulf & 2.07 & 1.99 & 1.80 & \\
\hline 14 & Courmayeur & 33.2 & 32.2 & 1.52 & \\
\hline 15 & Mont Blanc & 1.77 & 1.74 & 0.65 & \\
\hline 16 & Contrex & 29.9 & 29.3 & 1.15 & \\
\hline 17 & Hamidiye & 0.18 & 0.12 & 21.1 & - \\
\hline 18 & Bahçepinar & 0.09 & 0.29 & -51.4 & \\
\hline 19 & Thonon & 6.20 & 6.17 & 0.26 & \\
\hline
\end{tabular}


Applying this check technique, on data of 19 brands waters collected, exhibits that $36.8 \%$ of data (7 out of 19 measurements) exceeded the acceptance limit $( \pm 10 \%)$ of ionic balance error percent. This indicates that around one third of the samples have measuring or sampling errors, which means that the resultant data quality is insufficient for drawing reliable conclusions about water quality. Deviations from electroneutrality come from random or systematic error in one or more constituents or an incomplete analysis that neglects some significant constituent [29]. Seven bottled waters mineral (Bio, Iljano, Biyo Safi, Tayse-Le, Vitall, Bahçepinar, Hamidiye) presented an ionic balance error above $+/-10 \%$ are excluded from the analysis database. Therefore, 12 bottled waters mineral out of the 19 collected were selected for statistical analysis (Table 4).

\subsection{Chemical Characteristics and Compliance with Quality Standards of Bottled Water}

The maximum, minimum, standard deviation, mean and coefficient of variation (CV \%) values of the 9 chemical parameters of 12 bottled water brands selected out of 19 bottled marketed in Djibouti were determined and presented in Table 4. Comparison of these values with those by World Health Organization [30] and the United State Environment Protection Agency [31] are also shown in

Table 4. Descriptive statistics of the chemical composition of the bottled water brands (n $=12$ ).

\begin{tabular}{cccccccccc}
\hline Brands names & $\mathrm{pH}$ & $\begin{array}{c}\mathrm{HCO}_{3}^{-} \\
(\mathrm{mg} / \mathrm{l})\end{array}$ & $\begin{array}{c}\mathrm{Cl}^{-} \\
(\mathrm{mg} / \mathrm{l})\end{array}$ & $\begin{array}{c}\mathrm{NO}_{3}^{-} \\
(\mathrm{mg} / \mathrm{l})\end{array}$ & $\begin{array}{c}\mathrm{SO}_{4}^{2-} \\
(\mathrm{mg} / \mathrm{l})\end{array}$ & $\begin{array}{c}\mathrm{Ca}^{2+} \\
(\mathrm{mg} / \mathrm{l})\end{array}$ & $\begin{array}{c}\mathrm{Mg}^{2+} \\
(\mathrm{mg} / \mathrm{l})\end{array}$ & $\begin{array}{c}\mathrm{K}^{+} \\
(\mathrm{mg} / \mathrm{l})\end{array}$ & $\begin{array}{c}\mathrm{Na}^{+} \\
(\mathrm{mg} / \mathrm{l})\end{array}$ \\
\hline Okar & 7.3 & 30 & 40 & $<0.3$ & 5 & 8 & 13 & 2 & 8 \\
Palmaraie & 7.3 & 30 & 40 & $<0.3$ & 5 & 8 & 13 & 2 & 8 \\
Evian & 7.2 & 360 & 10 & 3.8 & 14 & 80 & 26 & 1 & 6.5 \\
Hépar & 7.2 & 383.7 & - & 4.3 & 1530 & 549 & 119 & - & 14.2 \\
Volvic & 7 & 74 & 15 & 7.3 & 9 & 12 & 8 & 6 & 12 \\
Hayat & 7.55 & 86.9 & 4.1 & - & 2.74 & 19.37 & 4.02 & $<0.2$ & 2.2 \\
Al ain & 7.3 & 30 & 40 & 0.3 & 5 & 8 & 13 & 2 & 8 \\
Super Gulf & 7.2 & 14 & 30 & 0.7 & 44 & 22 & 10 & 1.1 & 2.7 \\
Courmayeur & 7.7 & 170 & 0.3 & 2 & 1412 & 576 & 52 & 1.8 & 0.6 \\
Mont Blanc & 7.6 & 65 & 1 & 1 & 32 & 29 & 2.4 & 1.9 & 1.6 \\
Contrex & 7.4 & 372 & - & - & 1121 & 468 & 74.5 & - & 9.4 \\
Thonon & 7.4 & 340 & 14 & 8 & 12 & 92 & 16 & 1 & 6 \\
Max & 7.7 & 383.7 & 40 & 8 & 1530 & 576 & 119 & 6 & 14.2 \\
Min & 7 & 14 & 0.3 & $<0.3$ & 2.74 & 8 & 2.4 & $<0.2$ & 0.6 \\
Mean & 7.35 & 162.97 & 19.44 & 2.80 & 349.31 & 155.95 & 29.24 & 2.09 & 6.60 \\
Standard deviation & 0.19 & 147.52 & 15.68 & 2.79 & 586.69 & 219.33 & 33.88 & 1.44 & 4.05 \\
C.V \% & 2.57 & 90.52 & 80.68 & 9948 & 167.96 & 140.64 & 115.87 & 69.17 & 61.32 \\
\hline & & & & & & & & & \\
\hline & & & & & & & & &
\end{tabular}


Table 5. The chemical composition of natural water depends on many factors which includes chemistry of atmospheric precipitation, mineralogy of the rocks encountered along the flow path, residence time of the surface or groundwater, topography and climate [32] [33]. Hence, each bottled water brands has its own physical characteristics and chemical properties that are defined by a unique combination of these factors.

As can be seen in Table 4, the coefficient of variation of major constituents bottled water varies from $61.32 \%$ to $167.96 \%$ for ion concentration. Sulfate has the biggest coefficient of variation (167.96\%), followed by calcium (140.64\%), magnesium (115.87\%), nitrate (99.48\%), bicarbonate (90.52\%), chloride (80.68\%), potassium $(69.17 \%)$ and sodium $(61.32 \%)$. The values coefficient of variation showed that there a great variability between the water in terms of richness in chemical elements with the exception of $\mathrm{pH}$ which has a low coefficient of variation $(2.57 \%)$. In this study, two local bottled mineral waters (Palmaraie and Okar) have similar chemical composition (Table 4). This can be explained by the fact that the water comes exclusively from the same groundwater. Güler et al. pointed out the samples with similar chemical characteristics often have similar hydrologic histories, similar recharge areas, infiltration pathways, and flow paths in terms of climate, mineralogy, and residence time [32]. On the other hand, we see in Table 4 that the major ions in all brands demonstrate a great variations in composition which could be attributed to natural environment from which the water is taken (geological setting, climate, etc, ...), source water composition and type of treatment/purification technique(s) applied during the production [32]. Comparisons of the values chemical composition of the twelve brands water selected with those set by the United State Environment Protection Agency [31] and World Health Organization [30] international standards are also shown in Table 5.

Table 5. Quality of various bottled water brands sold in Djibouti compared to international standards $(\mathrm{n}=12)$.

\begin{tabular}{ccccc}
\hline Parameter & Unit & Water brands & WHO (2011) & USEPA (2016) \\
\hline $\mathrm{pH}$ & & $7-7.7$ & $6.5-8.5$ & $6.5-8.5$ \\
$\mathrm{HCO}_{3}^{-}$ & $\mathrm{mg} / \mathrm{l}$ & $14-383.7$ & 125 & - \\
$\mathrm{Cl}^{-}$ & $\mathrm{mg} / \mathrm{l}$ & $0.3-40$ & 250 & 250 \\
$\mathrm{NO}_{3}^{-}$ & $\mathrm{mg} / \mathrm{l}$ & $<0.3-8$ & 50 & 10 \\
$\mathrm{SO}_{4}^{2-}$ & $\mathrm{mg} / \mathrm{l}$ & $2.74-1530$ & 250 & 250 \\
$\mathrm{Ca}^{2+}$ & $\mathrm{mg} / \mathrm{l}$ & $8-576$ & 100 & 140 \\
$\mathrm{Mg}^{2+}$ & $\mathrm{mg} / \mathrm{l}$ & $2.4-119$ & 50 & - \\
$\mathrm{K}^{+}$ & $\mathrm{mg} / \mathrm{l}$ & $<0.2-6$ & 12 & 3,5 \\
$\mathrm{Na}^{+}$ & $\mathrm{mg} / \mathrm{l}$ & $0.6-14.2$ & 200 & 200 \\
\hline
\end{tabular}

WHO: World Health Organization; USEPA: United State Environmental Protection Agency. 
$\mathrm{pH}$ is a measure of the concentration of hydrogen ions and hydroxyl ions in water. The limit of $\mathrm{pH}$ value for drinking water is specified as 6.5 - 8.5 (Table 5). The $\mathrm{pH}$ of all brands was around neutral ranging from 7 to 7.7 with a mean of 7.35. All brands were within recommended prescribed by WHO and USEPA (Table 5). The $\mathrm{pH}$ has no direct impact on the consumer [34].

The Highest concentration of $\mathrm{HCO}_{3}$ is found in Hépar brands $(383.7 \mathrm{mg} / \mathrm{l})$, while the lowest recorded in Super Gulf was $14 \mathrm{mg} / \mathrm{l}$ with a mean $162.97 \mathrm{mg} / \mathrm{l}$. The source of bicarbonate is attributed to natural processes such as dissolution of carbonate mineral in the presence of $\mathrm{CO}_{2}$ in soil [35]. In the present study none of the local brands had $\mathrm{HCO}_{3}$ level exceeding the above standards, whereas five on the imported brands (Hépar, Contrex, Evian, Thonon and Courmayeur) have $\mathrm{HCO}_{3}$ levels that exceeded the standard guideline recommendations. It has been reported that, drinking of mineral water rich in bicarbonates prevent or improve type 2 diabetes in humans [36].

Concentration of $\mathrm{Cl}$ ranges from $0.3-40 \mathrm{mg} / \mathrm{l}$ with a mean of $19.44 \mathrm{mg} / \mathrm{l}$. Most of the water brands contain lower amounts of $\mathrm{Cl}$. None of the values exceeded the WHO and USEPA permissibles limits. An excess concentration of chloride $(>250 \mathrm{mg} / \mathrm{l})$ causes water to taste salty.

Concentration of $\mathrm{NO}_{3}$ in the studied water bottles varied from $<0.3$ to $8 \mathrm{mg} / \mathrm{l}$ with a mean of $2.80 \mathrm{mg} / \mathrm{l}$. All the water brands studied have $\mathrm{NO}_{3}$ levels falling short of WHO and USEPA limits. Nitrate is the most common chemical contaminant in the world's groundwater and aquifers. It can be converted in the stomach infants to nitrite $\left(\mathrm{NO}_{2}\right)$, which can then oxidize hemoglobin to methemoglobin, making it difficult to transport oxygen around the body [37] [38].

Table 4 shows that the $\mathrm{SO}_{4}$ concentration varied between 2.74 to $1530 \mathrm{mg} / \mathrm{l}$ with a mean of $349.31 \mathrm{mg} / \mathrm{l}$. However, three of the imported brands (Contrex, Courmayeur and Hépar) have sulfate levels that exceeded the recommendations of WHO and USEPA standards.

Concentration of Ca varied from 8 to $576 \mathrm{mg} / \mathrm{l}$ with a mean of $155.95 \mathrm{mg} / \mathrm{l}$. The minimum and maximum $\mathrm{Mg}$ concentration were 2.4 and $119 \mathrm{mg} / \mathrm{l}$ with a mean $29.24 \mathrm{mg} / \mathrm{l}$. However, three brands (Contrex, Courmayeur and Hépar) had Ca levels that exceeded the WHO and USEPA standards.

All the water brands have Mg levels well within the international standards limits expect two of the imported brands (Contrex and Hépar). They exceed 50 $\mathrm{mg} / \mathrm{l}$ level recommended by WHO standards.

Regarding the concentration of $\mathrm{Na}$ ranging from 0.6 to $14.2 \mathrm{mg} / \mathrm{l}$ with a mean of $6.60 \mathrm{mg} / \mathrm{l}$, they were very well within the recommended WHO and USEPA standard limits for drinking water.

As can be seen from Table 4, the potassium level varied $<0.2$ to $6 \mathrm{mg} / \mathrm{l}$ with a mean of $2.09 \mathrm{mg} / \mathrm{l}$. None of the values exceeded the maximum limit of $12 \mathrm{mg} / \mathrm{l}$ set by $\mathrm{WHO}$ ).

\subsection{Classification Based on Total Hardness}

Water hardness is caused by minerals, such as magnesium and calcium. The to- 
tal water hardness, as $\mathrm{Ca}^{2+}$ and $\mathrm{Mg}^{2+}$ ions, was calculated according to Equation (3) [39].

$$
\text { Total Hardness }=2.5\left[\mathrm{Ca}^{2+}\right]+4.1\left[\mathrm{Mg}^{2+}\right]
$$

where $\left[\mathrm{Ca}^{2+}\right]$ and $\left[\mathrm{Mg}^{2+}\right]$ are the concentrations of calcium and magnesium (in $\mathrm{mg} / \mathrm{l})$ displayed on the bottled labels, while 2.5 and 4.1 are their molar mass ratios per $100 \mathrm{~g}$ of $\mathrm{CaCO}_{3}$.

Bottled water brands for this study were classified based on total hardness (TH) as shown in Table 6. General guidelines for classification of water are: 0 to $60 \mathrm{mg} / \mathrm{L}$ as calcium carbonate is classified as soft; 61 to $120 \mathrm{mg} / \mathrm{L}$ as moderately hard; 121 to $180 \mathrm{mg} / \mathrm{L}$ as hard; and more than $180 \mathrm{mg} / \mathrm{L}$ as very hard [40]. According to this classification, water hardness of the bottled water ranged from 62.8 to $1860.4 \mathrm{mg} / \mathrm{l} \mathrm{CaCO}_{3}$ with a mean value of $509.8 \mathrm{mg} / \mathrm{l}$ (Table 6). Seven of the brands with hardness between 62.8 and $96 \mathrm{mg} / \mathrm{l}$ are considered moderately hard and five brands with hardness between 295.6 and $1860.4 \mathrm{mg} / \mathrm{l}$ are considered very hard. All the 12 brands bottled are qualified by hard water category. Hardness of water which is due to the presence of calcium and magnesium salts in water, does contribute towards total calcium and magnesium human dietary needs, which has a beneficial effect on bone structure [40]. Water hardness has no known adverse effects. However, some evidence indicates its role in heart disease [41]. Moreover, epidemiological studies suggest that consumption of $\mathrm{Mg}$ may reduce the frequency of sudden death and Ca may help prevent osteoporosis in humans [42].

The WHO limits hardness for drinking water between $100-500 \mathrm{mg} / \mathrm{l}$. It may be seen from Table 6 that the total water hardness of all the three water brands (Hépar, Courmayeur and Contrex) is above than the limits established by WHO/USEPA. They can be crucial in the prevention of magnesium deficiency,

Table 6. Classification of the bottled water brands based on total hardness $(n=12)$.

\begin{tabular}{ccc}
\hline Brands names & Total Hardness $(\mathrm{mg} / \mathrm{l})$ & Water class \\
\hline Okar & 73.3 & moderately hard \\
Palmaraie & 73.3 & moderately hard \\
Evian & 306.6 & very hard \\
Hépar & 1860.4 & very hard \\
Volvic & 62.8 & moderately hard \\
Hayat & 64.9 & moderately hard \\
Al ain & 73.3 & moderately hard \\
Super Gulf & 96 & moderately hard \\
Courmayeur & 1653.2 & very hard \\
Mont Blanc & 82.3 & moderately hard \\
Contrex & 1475.5 & very hard \\
Thonon & 295.6 & very hard \\
\hline
\end{tabular}


as well as contribute significantly to the daily calcium intake for persons with calcium deficient diets. However, the use of very hard water for infants or pregnant women is not recommended.

\subsection{Water Type}

In this study, the water type is defined by all ionic constituents that contribute at least $25 \%$ to the total anionic or cationic composition of water (Table 7). The most frequently observed water type is $\mathrm{Mg}-\mathrm{Ca}-\mathrm{Cl}-\mathrm{HCO}_{3}$ and $\mathrm{Ca}-\mathrm{Mg}-\mathrm{HCO}_{3}$. All the studied water brands are dominated by either $\mathrm{Ca}$ or $\mathrm{Mg}$ except two brands (Courmayeur and Mont Blanc), which are dominated by $\mathrm{Ca}-\mathrm{SO}_{4}$ and $\mathrm{Ca}-\mathrm{HCO}_{3}-\mathrm{SO}_{4}$.

Bottled water is classified into eight major water types according to the Piper's diagram (Figure 1).

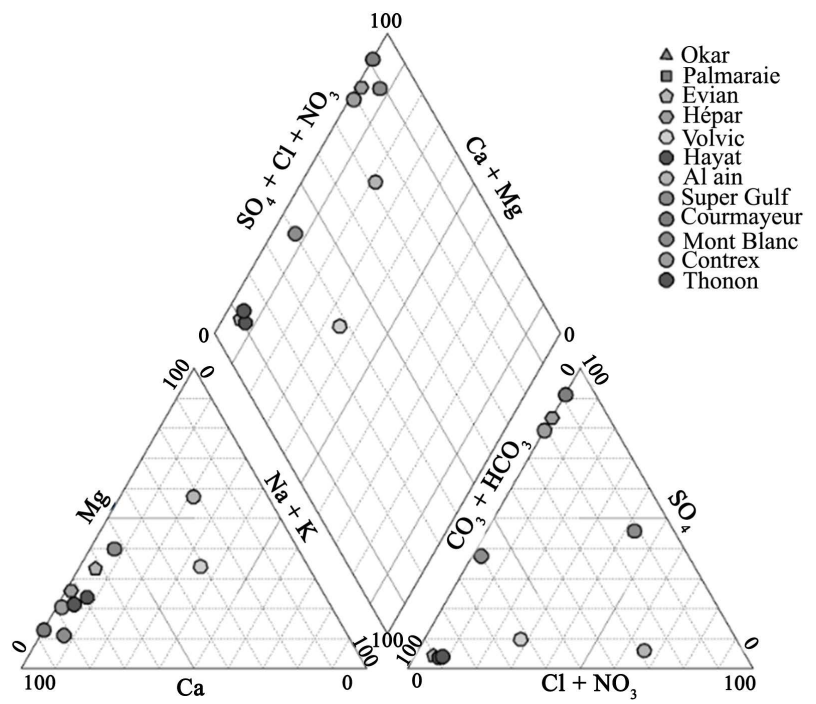

Figure 1. Piper diagram for the bottled water brands $(n=12)$.

Table 7. Eight different water types of the bottled water brands $(n=12)$.

\begin{tabular}{cc}
\hline Brands names & Water type \\
Okar & $\mathrm{Mg}-\mathrm{Ca}-\mathrm{Cl}-\mathrm{HCO}_{3}$ \\
Palmaraie & $\mathrm{Mg}-\mathrm{Ca}-\mathrm{Cl}-\mathrm{HCO}_{3}$ \\
Hépar & $\mathrm{Ca}-\mathrm{Mg}-\mathrm{HCO}_{3}$ \\
Volvic & $\mathrm{Ca}-\mathrm{Mg}-\mathrm{SO}_{4}$ \\
Hayat & $\mathrm{Mg}-\mathrm{Ca}-\mathrm{Na}-\mathrm{HCO}_{3}-\mathrm{Cl}$ \\
Al ain & $\mathrm{Ca}-\mathrm{Mg}-\mathrm{HCO}_{3}$ \\
Super Gulf & $\mathrm{Mg}-\mathrm{Ca}-\mathrm{Cl}_{-}-\mathrm{HCO}_{3}$ \\
Courmayeur & $\mathrm{Ca}-\mathrm{Mg}-\mathrm{SO}_{4}-\mathrm{Cl}$ \\
Mont Blanc & $\mathrm{Ca}-\mathrm{SO}_{4}$ \\
Contrex & $\mathrm{Ca}-\mathrm{HCO}-\mathrm{SO}_{4}$ \\
Thonon & $\mathrm{Ca}-\mathrm{Mg}-\mathrm{SO}_{4}-\mathrm{HCO}_{3}$ \\
& $\mathrm{Ca}-\mathrm{Mg}_{2}-\mathrm{HCO}_{3}$
\end{tabular}


In order to perform a comparison between different bottled water types, main components ( $\mathrm{Na}, \mathrm{K}, \mathrm{Ca}, \mathrm{Mg}, \mathrm{Cl}, \mathrm{SO}_{4}$ and $\mathrm{HCO}_{3}$ ) of the 12 bottled waters selected among 19 are plotted on the Piper diagram [43]. The diagram displays the relative concentrations of the major cations and anions on two separate trilinear plots, together with a central diamond plot where points from two trilinear plots are projected. As shown in Figure 1, most of the water brands are $\mathrm{Ca}, \mathrm{Mg}$, $\mathrm{HCO}_{3}, \mathrm{SO}_{4}$ and $\mathrm{Cl}$ type water.

The Pearson's correlation coefficient between major ions in bottled water brands $(\mathrm{n}=12)$ are presented in Table 8 . The variables having coefficient value $(\mathrm{r})>0.5$ are considered significant. Strong positive correlations between $\mathrm{SO}_{4}$ and $\mathrm{Ca}(\mathrm{r}=0.99), \mathrm{SO}_{4}$ and $\mathrm{Mg}(\mathrm{r}=0.91), \mathrm{Ca}-\mathrm{Mg}(\mathrm{r}=0.89), \mathrm{HCO}_{3}$ and $\mathrm{Mg}(\mathrm{r}=0.70)$, $\mathrm{HCO}_{3}$ and $\mathrm{Ca}(\mathrm{r}=0.63), \mathrm{HCO}_{3}$ and $\mathrm{NO}_{3}(\mathrm{r}=0.56), \mathrm{HCO}_{3}$ and $\mathrm{SO}_{4}(\mathrm{r}=0.55)$, $\mathrm{Mg}$ and $\mathrm{Na}(\mathrm{r}=0.50)$ and $\mathrm{K}$ and $\mathrm{Na}(\mathrm{r}=0.51)$. No significant correlations were obtained for $\mathrm{Cl}$ and $\mathrm{NO}_{3}$ with the others variables, and this corresponds well to their chemical composition which was low in all the bottled water brands.

PCA of the water quality variables extracts two components with eigenvalue > 1.0 according to the method of the percentage of inertia. This method resulted in two principal components (PC1 and PC2), which account $~ 68.67 \%$ of the total variance in the dataset (Table 9). Figure 2 shows results of the PCA analysis for 12 brands of bottled waters. Analysing the projections of the variables on the factorial plane by plotting PC1 against PC2 (Figure 2) and respective PC contribution (Table 9), it is concluded that the first principal component (PC1) accounted for $45.85 \%$ of the total variance and is characterized by high positive contribution of $\mathrm{Mg}, \mathrm{Ca}, \mathrm{SO}_{4}$ and $\mathrm{HCO}_{3}$ (with contribution $95 \%, 92 \%, 91 \%$ and $83 \%$, respectively). This component appears to be clearly dependent on geological composition of the substrate, being located mostly in association with carbonate rocks [9] [18]. This PC1 may be considered as an index of water hardness which $\mathrm{Ca}$ and $\mathrm{HCO}_{3}$ are the major dissolved species in limestone aquifers, while the presence of $\mathrm{Mg}$ is attributed to either magnesian calcite or dolomite [44].

Table 8. Pearson's correlation coefficients between major ions in bottled water brands (n $=12$ ).

\begin{tabular}{ccccccccc}
\hline & $\mathrm{HCO}_{3}^{-}$ & $\mathrm{Cl}^{-}$ & $\mathrm{NO}_{3}^{-}$ & $\mathrm{SO}_{4}^{2-}$ & $\mathrm{Ca}^{2+}$ & $\mathrm{Mg}^{2+}$ & $\mathrm{K}^{+}$ & $\mathrm{Na}^{+}$ \\
\hline $\mathrm{HCO}_{3}^{-}$ & 1.00 & & & & & & & \\
$\mathrm{Cl}^{-}$ & -0.37 & 1.00 & & & & & & \\
$\mathrm{NO}_{3}^{-}$ & 0.56 & -0.36 & 1.00 & & & & & \\
$\mathrm{SO}_{4}^{2-}$ & $\mathbf{0 . 5 5}$ & -0.27 & 0.01 & 1.00 & & & \\
$\mathrm{Ca}^{2+}$ & $\mathbf{0 . 6 3}$ & -0.33 & 0.07 & 0.99 & 1.00 & & \\
$\mathrm{Mg}^{2+}$ & $\mathbf{0 . 7 0}$ & -0.09 & 0.14 & 0.91 & 0.89 & 1.00 & & \\
$\mathrm{~K}^{+}$ & -0.24 & 0.10 & 0.26 & -0.01 & -0.06 & -0.04 & 1.00 & \\
$\mathrm{Na}^{+}$ & 0.34 & 0.43 & 0.41 & 0.21 & 0.16 & 0.50 & 0.51 & 1.00 \\
\hline
\end{tabular}


Facteur 2

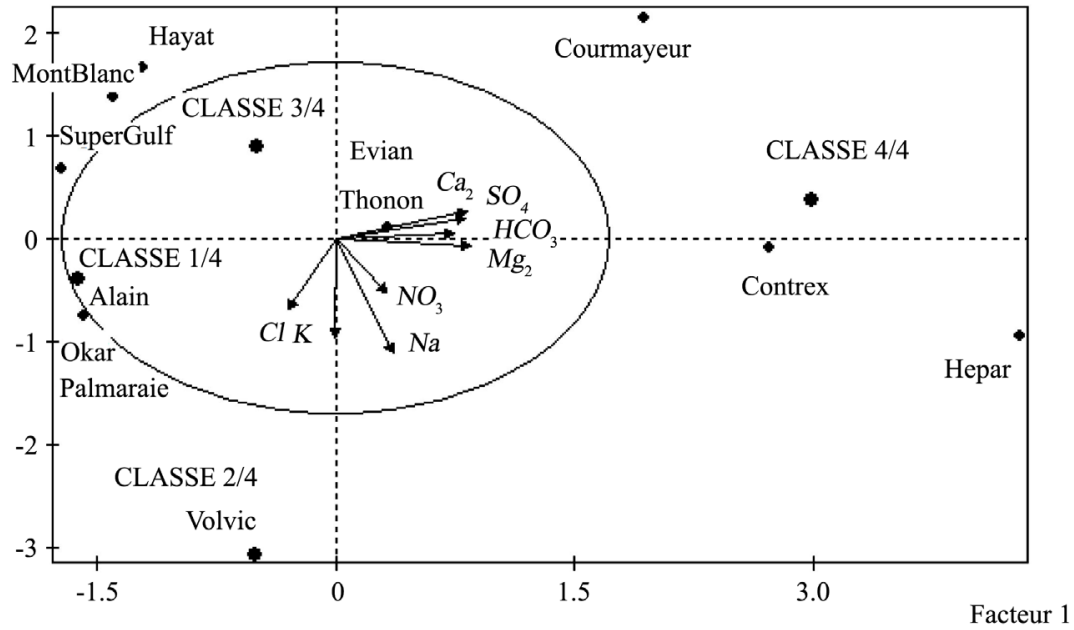

Facteur 1 represents the first principal component (PC1) and Facteur 2 the second principal component (PC2)

Figure 2. Projection of the four hydrochemical groups in the factorial plane.

Table 9. Total variance explained and component matrix for major ions.

\begin{tabular}{ccc}
\hline Parameter & Component 1 & Component 2 \\
\hline $\mathrm{HCO}_{3}$ & 0.83 & 0.04 \\
$\mathrm{Cl}$ & -0.33 & -0.52 \\
$\mathrm{NO}_{3}$ & 0.36 & -0.40 \\
$\mathrm{SO}_{4}$ & 0.91 & 0.16 \\
$\mathrm{Ca}$ & 0.92 & 0.21 \\
$\mathrm{Mg}$ & 0.95 & -0.06 \\
$\mathrm{~K}$ & -0.01 & -0.75 \\
$\mathrm{Na}$ & 0.41 & -0.87 \\
Eigenvalue & 3.6676 & 1.8257 \\
Variance (\%) & 45.85 & 22.82 \\
Cumulative of variance (\%) & 45.85 & 68.67 \\
\hline
\end{tabular}

The second Principal Component (PC2) represents $22.82 \%$ of the total variance within the data and is characterized by negative contribution in $\mathrm{K}, \mathrm{Na}$ and $\mathrm{Cl}$ (with contribution $75 \%, 87 \%$ and 52\%, respectively). This component represents dissolution of the evaporite rocks.

HCA was used to find the natural grouping of the 12 bottled waters selected out of the nineteen waters brands marketed in Djibouti in accordance with chemical composition parameters. The result of the HCA is presented in the form of a dendrogram (Figure 3). Based on eight parameters, the HCA classified 12 bottled waters brands in four groups. The first group is composed of three brands (Contrex, Hépar and Courmayeur), the second grouped four brands (Evian, Hayat, Mont Blanc and Thonon), the third contained one brand (Volvic) 


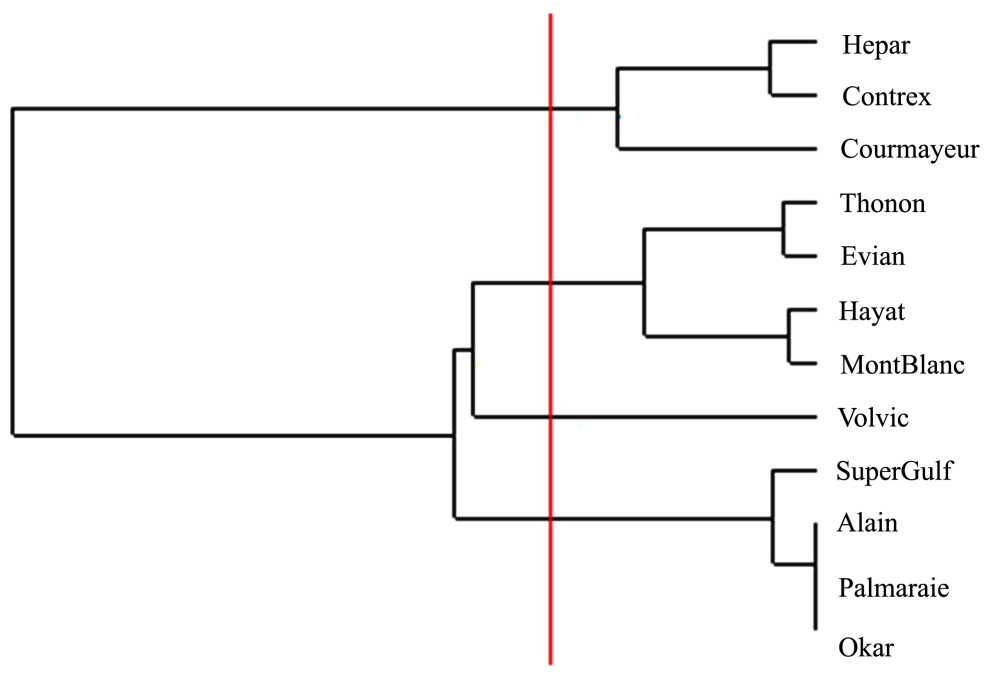

Figure 3. Hierarchical dendrogram from the HCA for the 12 bottled waters brands.

and the fourth groups comprised four brands (Alain, Okar, Palmaraie and Super Gulf).Two local bottled (Okar and Palmaraie) are of similar ionic profile as bottled water imported ( $\mathrm{Al}$ ain) according to the amount of 8 major ions. The characteristic parameter of the first group is $\mathrm{Cl}$ (ion related to the salinity of the water) and the forth group is $\mathrm{SO}_{4}, \mathrm{Ca}$ and $\mathrm{Mg}$ (result the dissolution of the carbonate rocks). Or the second and third groups have no characteristic parameter. The results of HCA coincide with those obtained from PCA.

\section{Conclusions}

Water is essential for human life. The increasing salinity of tap water in Djibouti has led to a high demand for bottled mineral water accompanied by local production and import of several new water brands with a different origin and physico-chemical composition.

Firstly, the chemical composition of the nineteen bottled mineral waters has made the subject of a first verification by Ionic Balance Error (IBE). Applying this check technique on data of 19 brands waters collected, exhibits that $36.8 \%$ of data (7 out of 19 measurements) exceeded the acceptance limit $( \pm 10 \%)$ of ionic balance error percent. However, 12 brands waters had an acceptable charge balance error. Data of these 12 brands were subjected to different pattern recognition methods such as correlation analysis, as Correlation Analysis (CA), Principal Component Analysis (PCA) and Hierarchical Cluster Analysis (HCA). The application of descriptive methods of different multivariate statistical techniques was shown to be effective tools in the identification of the principal interrelationships of the major ions of the studied bottled waters, thereby indicating their similarities and dissimilarities. The obtained results showed that HCA classified the water brands into four different groups based on the similarity of water quality characteristics. PCA identified two factors, which carry $\sim 68.67 \%$ of the total variance of the dataset. HCA confirmed the results of PCA. The chemical composition of local and imported bottled water brands was also compared with 
World Health Organization (WHO) and United State Environment Protection Agency (USEPA) standards. Majority of the studied brands is classified as moderately to very hard water. The classification resulting from this statistical study does not give the privilege to any water brands. The main result that can be exploited at this level is to allow consumers to expand the range of choices of water brands having similarities in terms of chemical composition.

\section{Conflicts of Interest}

The authors declare no conflicts of interest regarding the publication of this paper.

\section{References}

[1] International Monetary Fund (2004) Djibouti: Poverty Reduction Strategy Paper. 22. https://doi.org/10.5089/9781451810646.002

[2] Etale, A., Jobin, M. and Siegrist, M. (2018) Tap versus Bottled Water Consumption: The Influence of Social Norms, Affect and Image on Consumer Choice. Appetite, 121, 138-146. https://doi.org/10.1016/j.appet.2017.11.090

[3] Doria, M.F. (2006) Bottled Water versus Tap Water: Understanding Consumers Preferences. Journal of Water and Health, 4, 271-276. https://doi.org/10.2166/wh.2006.0023

[4] Karg, T. https://www.bevindustry.com/articles/91268-2018-state-of-the-beverage-industry-b ottled-water-remains-the-no-1-beverage-in-the-unitedstates

[5] Labadi, A.S. and Hammache, H. (2016) Comparative Study of Mineral Waters and Spring Waters Produced in Algeria. Larhyss Journal, 28, 319-342.

[6] Chambre De Commerce De Djibouti. http://www.ccd.dj/w2017/wp-content/uploads/2016/01/iaa.pdf

[7] Ikem, A.S., Odueyungbo, N.O. and Nyavor, E.K. (2002) Chemical Quality of Bottled Waters from Three Cities in Eastern Alabama. Science of the Total Environment, 285, 165-175. https://doi.org/10.1016/S0048-9697(01)00915-9

[8] Hoch, F.B. and Awaleh, M.O. (2014) Développement et validation d'une méthode d'analyse des ions bromates à l'état trace dans les eaux embouteillées de la République de Djibouti. Science et Environnement, 27, 52-72.

[9] Eggenkamp, H.G.M. and Marques, J.M.A. (2013) Comparison of Mineral Water Classification Techniques: Occurrence and Distribution of Different Water Types in Portugal (Including Madeira and the Azores). Journal of Geochemical Exploration, 132, 125-139. https://doi.org/10.1016/j.gexplo.2013.06.009

[10] Ghasemi, J.B., Zolfonoun, E. and Khosrokhavar, R. (2013) Linear and Nonlinear Multivariate Classification of Iranian Bottled Mineral Waters According to Their Elemental Content Determined by ICP-OES. Journal of Sciences, Islamic Republic of Iran, 24, 15-22.

[11] Felipe-Sotelo, M., Henshall-Bell, E.R., Evans, N.D.M. and Read, D. (2015) Comparison of the Chemical Composition of British and Continental European Bottled Waters by Multivariate Analysis. Journal of Food Composition and Analysis, 39, 33-42. https://doi.org/10.1016/j.jfca.2014.10.014

[12] Azhar, S.C., Aris, A.Z., Yusoff, M.K., Ramli, M.F. and Juahir, H. (2015) Classification of River Water Quality Using Multivariate Analysis. Procedia Environmental Sciences, 
30, 79-84. https://doi.org/10.1016/j.proenv.2015.10.014

[13] Özdemir, Ö. (2016) Application of Multivariate Statistical Methods for Water Quality Assessment of Karasu-Sarmisakli Creeks and Kizilirmak River in Kayseri, Turkey. Polish Journal of Environmental Studies, 25, 1149-1160. https://doi.org/10.15244/pjoes/61850

[14] Tiri, A., Lahbari, N. and Boudoukha, A. (2017) Assessment of the Quality of Water by Hierarchical Cluster and Variance Analyses of the Koudiat Medouar Watershed, East Algeria. Applied Water Science, 7, 4197-4206. https://doi.org/10.1007/s13201-014-0261-Z

[15] Aydin Uncumusaöglu, A. (2018) Statistical Assessment of Water Quality Parameters for Pollution Source Identification in Bektaş Pond (Sinop, Turkey). Global NEST Journal, 20, 151-160. https://doi.org/10.30955/gnj.002369

[16] Russel, C.G.C., Lazarus, S., Isaac, C. and Khaldoon, A.M. (2019) Standards Compliance and Health Implications of Bottled Water in Malawi. International Journal of Environmental Research and Public Health, 16, 951. https://doi.org/10.3390/ijerph16060951

[17] Alhassan, H.I., Zowain, A. and Sufar, E.K.H. (2013) Quality Assessment of Various Local Bottled Waters in Different Iraqi Markets. Engineering and Technology Journal, 31, 660-677.

[18] Ghrefat, H.A. (2013) Classification and Evaluation of Commercial Bottled Drinking Waters in Saudi Arabia. Research Journal of Environmental and Earth Sciences, 5, 210-218. https://doi.org/10.19026/rjees.5.5716

[19] Astel, A., Michalski, R., Lyko, A., Jablonska-Czapla, M., Bigus, K., Szopa, S. and Kwiecinska, A. (2014) Characterization of Bottled Mineral Waters Marketed in Poland Using Hierarchical Cluster Analysis. Journal of Geochemical Exploration, 143, 136-145. https://doi.org/10.1016/j.gexplo.2014.04.002

[20] Cvejanoc, J.D. and Skrbic, B.D. (2017) Application of Principal Component and Hierarchical Cluster Analyses in the Classification of Serbian Bottled Waters and a Comparison with Waters from Some Other European Countries. Journal of the Serbian Chemical Society, 82, 711-721. https://doi.org/10.2298/JSC170219034C

[21] Sghaier, T. and Ben Abdallah, M.A. (2018) Comparative Study of the Physicochemical Composition of Twenty Packaged Water Brands Marketed in Tunisia. Journal of New Sciences, Agriculture and Biotechnology, 56, 3671-3686.

[22] Versari, A., PaoloParpinello, G. and Galassi, S. (2002) Chemometric Survey of Italian Bottled Mineral Waters by Means of Their Labelled Physico-Chemical. Journal of Food Composition and Analysis, 15, 251-264. https://doi.org/10.1006/jfca.2002.1058

[23] Güler, C. (2007) Characterization of Turkish Bottled Waters Using Pattern Recognition Methods. Chemometrics and Intelligent Laboratory, 86, 86-94. https://doi.org/10.1016/j.chemolab.2006.08.009

[24] Yekdeli Kermanshahi, K., Tabaraki, R., Karimi, H., Nikorazm, M. and Abbasi, S. (2010) Classification of Iranian Bottled Waters as Indicated by Manufacturer's Labellings. Food Chemistry, 120, 1218-1223.

https://doi.org/10.1016/j.foodchem.2009.11.067

[25] Davis, J.C. (1986) Statistics and Data Analysis in Geology. Second Edition, John Wiley and Sons Inc., New York.

[26] Lewi, P.J. (1992) Multivariate Data Display. In: Brereton, R.G., Ed., Multivariate Pattern Recognition in Chemometrics, Elsevier, London, 43-70. https://doi.org/10.1016/S0922-3487(08)70202-8 
[27] Kaiser, H.F. (1960) The Application of Electronic Computers to Factor Analysis. Educational and Psychological Measurement, 20, 141-151. https://doi.org/10.1177/001316446002000116

[28] Freeze, R.A. and Cherry, J.A. (1979) Groundwater. Prentice-Hall Inc., Englewood Cliffs.

[29] Hem, J.D. (1985) Study and Interpretation of the Chemical Characteristics of Natural Water. 3rd Edition, United States Geological Survey Water-Supply Paper 2254, 165.

[30] World Health Organization (WHO) (2017) Guidelines for Drinking Water Quality. 4th Edition, Incorporating the First Addendum, WHO, Geneva.

[31] United States Environmental Protection Agency (2016) Drinking Water Standards. Web, New York.

[32] Güler, C., Thyne, G.D., Mccray, J.E. and Keith Turner, A. (2002) Evaluation of Graphical and Multivariate Statistical Methods for Classification of Water Chemistry Data. Hydrogeology Journal, 10, 455-474. https://doi.org/10.1007/s10040-002-0196-6

[33] Khatri, N. and Tyagi, S. (2015) Influences of Natural and Anthropogenic Factors on Surface and Groundwater Quality in Rural and Urban Areas. Frontiers in Life Science, 8, 23-39. https://doi.org/10.1080/21553769.2014.933716

[34] Khalid Hasan, M.D., Shahriar, A. and Ullah Jim, K. (2019) Water Pollution in Bangladesh and Its Impact on Public Health. Heliyon, 5, 21-45.

https://doi.org/10.1016/j.heliyon.2019.e02145

[35] Belkhiri, L. and Mouni, L. (2014) Geochemical Characterization of Surface Water and Groundwater in Soummam Basin, Algeria. Natural Resources Research, 23, 393-407. https://doi.org/10.1007/s11053-014-9243-y

[36] Murakami, S., et al. (2015) The Consumption of Bicarbonate-Rich Mineral Water Improves Glycemic Control. Evidence-Based Complementary and Alternative Medicine, 2015, Article ID: 824395. https://doi.org/10.1155/2015/824395

[37] Özdestan, Ö. and Üren, A. (2012) Nitrate and Nitrate Contents of Baby Foods. Akademik Gida, 10, 11-18.

[38] Ghayebzadeh, M., Esmaeili, L. and Mohammadi, M. (2017) Association of Nitrate Levels in Drinking Water and Infantile Methemoglobinemia. Biomedical and Health, 2, 212-223.

[39] Crittenden, J.C., Trussell, R., Hand, D.W., Howe, K.J. and Tchobanoglous, G. (2005) Water Treatment: Principles and Design. 2nd Edition, John Wiley, Hoboken.

[40] Sengupta, P. (2013) Potential Health Impacts of Hard Water. International Journal of Preventive Medicine, 4, 866-875.

[41] Schroeder, H.A. (1960) Relations between Hardness of Water and Death Rates from Certain Chronic and Degenerative Diseases in the United States. Journal of Chronic Diseases, 12, 586-591. https://doi.org/10.1016/0021-9681(60)90002-3

[42] Garzon, P. and Eisenberg, M.J. (1998) Variation in the Mineral Content of Commercially Available Bottled Waters: Implications for Health and Disease. The American Journal of Medicine, 105, 125-130. https://doi.org/10.1016/S0002-9343(98)00189-2

[43] Piper, A.M. (1944) A Graphic Procedure in the Geochemical Interpretation of Water-Analyses. Transactions of the American Geophysical Union, 25, 914-923. https://doi.org/10.1029/TR025i006p00914

[44] Oyebog, S.A., Ako, A.A., Nkeng, G.E. and Suh, E.C. (2012) Hydrogeochemical 
Characteristics of Some Cameroon Bottled Waters, Investigated by Multivariate Statistical Analyses. Journal of Geochemical Exploration, 112, 118-130.

https://doi.org/10.1016/j.gexplo.2011.08.003 